\title{
Minimising exposure of amphibians to pathogens during field studies
}

\author{
A. D. Phillott ${ }^{1,2, *}$, R. Speare ${ }^{1,2}$, H. B. Hines ${ }^{3}$, L. F. Skerratt ${ }^{1,2}$, E. Meyer ${ }^{4}$, \\ K. R. McDonald ${ }^{5,2}$, S. D. Cashins ${ }^{1,2,6}$, D. Mendez ${ }^{1,2}$, L. Berger ${ }^{1,2}$ \\ ${ }^{1}$ School of Public Health, Tropical Medicine and Rehabilitation Sciences, James Cook University, Townsville, \\ Queensland 4811, Australia \\ ${ }^{2}$ Amphibian Disease Ecology Group, James Cook University, Townsville, Queensland 4811, Australia \\ ${ }^{3}$ Threatened Species Branch, Department of Environment and Resource Management, PO Box 64, Bellbowrie, \\ Queensland 4070, Australia \\ ${ }^{4} 5$ Luscombe Street, Runcorn, Queensland 4113, Australia \\ ${ }^{5}$ Threatened Species Branch, Department of Environment and Resource Management, PO Box 975, Atherton, \\ Queensland 4883, Australia \\ ${ }^{6}$ School of Marine and Tropical Biology, James Cook University, Townsville, Queensland 4811, Australia
}

\begin{abstract}
Many of the recent global amphibian mass mortalities, declines and extinctions have been attributed to the emerging infectious disease chytridiomycosis. There have been mass mortalities due to ranaviral disease but no major declines or extinctions. Controlling the transmission and spread of disease is of utmost importance, especially where there is the potential for human involvement. We have reviewed current hygiene guidelines for working with wild frogs, identified potential flaws and recommended those most suitable and effective for the field environment. Our within-site hygiene measures aim to reduce the risk of transmission among individuals. These measures encompass the capture, handling and holding of amphibians, skin disinfection before and after invasive procedures, marking frogs, sealing open wounds and treatment of accessory equipment. Our between-site hygiene measures aim to mitigate the risk of pathogen spread among populations. We have designed a risk calculator to help simplify and standardise the decision-making process for determining the level of risk and appropriate risk mitigation strategies to reduce the risk of increasing pathogen spread above background levels. Calculation of an overall risk score for pathogen spread takes into account the prior activity of field workers, the proposed activity, remoteness of the site, presence of known pathogens and the consequences of increased pathogen spread for amphibians in a given area.
\end{abstract}

KEY WORDS: Chytridiomycosis · Hygiene · Batrachochytrium dendrobatidis · Ranaviral disease · Ranavirus · Field study

\section{INTRODUCTION}

The past $30 \mathrm{yr}$ has seen alarming declines and extinctions of amphibians world wide. The recently emerged disease, chytridiomycosis, has caused mass mortalities, major declines and extinctions, and ranaviral disease has caused mass mortalities (Cunningham et al. 1996, Berger et al. 1998, Daszak et al. 1999, Long- core et al. 1999, Green et al. 2002, Muths et al. 2003, Lips et al. 2006, Schloegel et al. 2006, Picco et al. 2007, Skerratt et al. 2007). The consequences of introducing these or other serious pathogens into naïve amphibian populations are likely to be severe (Berger et al. 1999, Pearman et al. 2004, Weldon et al. 2004, Cunningham et al. 2005, Jancovich et al. 2005, Lips et al. 2006, 2008, Fisher \& Garner 2007, Skerratt et al. 2007). 
Unregulated trade in amphibians, as well as unintentional shipment, is suspected to have been a major contributor to the spread of these diseases (Weldon et al. 2004, Fisher \& Garner 2007, Skerratt et al. 2007). To curb their spread, the World Organisation for Animal Health (OIE) has made these diseases notifiable (OIE 2008). Preventing the spread of these amphibian diseases across international borders is of great importance, but it is also important to control disease spread within national borders (i.e. domestically).

The potential for human involvement in transmission (passing of disease from an infected to an uninfected individual) and spread (movement of disease geographically) of these diseases, within and among amphibian populations, appears to be significant (Mutschmann et al. 2000, Raverty \& Reynolds 2001, Parker et al. 2002, Mazzoni et al. 2003, Hanselmann et al. 2004, Weldon et al. 2004, Jancovich et al. 2005, Oevermann et al. 2005, Daszak et al. 2006, Picco et al. 2007, Picco \& Collins 2009). Of particular concern is the potential for field biologists to spread disease amongst wild populations.

While evidence directly implicating field biologists in the spread of amphibian diseases is currently lacking, the hazard of disease transmission and spread by biologists must be considered. For researchers working with amphibians or within areas of amphibian habitat, the risk of disease transmission within these habitats and the spread of disease among populations may be increased due to (1) frequent handling of amphibians, (2) frequent or rapid movement between isolated areas of habitat and (3) rapid or frequent movement between captive husbandry and laboratory facilities and the field. It is therefore important that biologists working with amphibians or within amphibian habitats take care to minimise disease transmission and spread both within and among amphibian populations. This is especially important where rare, geographically restricted or threatened amphibian species are concerned and when the spread of disease can have serious consequences for species survival.

Field researchers should, therefore, evaluate their activities to determine their relative risk of pathogen transmission and spread compared with background levels (i.e. the risk posed by other mechanisms of disease transmission or pathogen dispersal) and implement appropriate strategies to minimise this risk during field studies. It must be recognised that the overall risk of transmission and spread of pathogens cannot be reduced below the background level by risk mitigation during research or monitoring activities. Therefore, the aim of risk mitigation is to prevent risk increasing above background levels (i.e. the risk posed by other mechanisms of disease transmission or pathogen dispersal). The risk of transmission and spread should be evaluated by researchers, animal ethics committees and government agencies issuing permits. However, we do not advocate the cessation of field-based research or monitoring as a risk management strategy. The value of the research outcome needs to be balanced with the disease risk posed to individuals and, more importantly, to populations of amphibians. In addition, the presence of infectious disease (caused by pathogens) should not be confused with that of non-infectious diseases such as most cancers, which cannot be transmitted between animals.

Current hygiene guidelines for handling wild frogs (Daszak et al. 2001, NSW NPWS 2001, NWHC 2001, HACC 2004, Speare et al. 2004, Aguirre \& Lampo 2006, CCADC 2008) seek to minimise transmission of infectious diseases; however, some guidelines are contradictory and potentially harmful to amphibians (e.g. the use of iodine compounds for surgical disinfection). Here we review the suggested practices for minimising the spread of infectious diseases within sites and make recommendations for those most suitable and effective in the field environment. In addition, existing hygiene protocols identify the importance of between-site measures to reduce pathogen spread but lack a framework for determining the stringency and scale at which between-site measures are applied. To help inform such decisions we present a risk calculator that enables field biologists to assess the relative risk (above background levels) of their activities and the hazard they pose to amphibian populations. This approach is similar to that currently employed by Biosecurity Australia and other member countries of the OIE during import risk assessments (AGDAFF 2009). Our recommendations are aimed at amphibian pathogens known to result in widespread mortality, namely Batrachochytrium dendrobatidis and ranaviruses, but will also be effective against other pathogens.

\section{WITHIN-SITE HYGIENE MEASURES}

\section{Capture, handling and holding wild amphibians}

Capture, handling and housing of wild amphibians should be minimised or avoided where possible, as stressed animals are at greater risk of infection (Carey et al. 1999, Daszak et al. 2003). Direct microbial transfer during capture and handling of successive adult amphibians can be reduced by wearing single-use gloves (latex, nitrile or vinyl) or capturing and handling frogs in single use lightweight plastic bags. Some tadpoles suffer lethal effects when exposed to latex, nitrile and, to a lesser extent, vinyl gloves, although some of these effects can be mitigated by washing the gloves before handling (Gutleb et al. 2001, Cashins et 
al. 2008). Larvae should, therefore, be handled with gloves that have been proven or rendered safe for that species. Data suggest the causative pathogen of chytridiomycosis, Batrachochytrium dendrobatidis, does not survive on bare human hands for long; however, this killing effect is reduced with repeated hand washing in water (Mendez et al. 2008). It is unknown whether ranaviruses remain viable following contact with human skin. We therefore recommend that single-use gloves be worn during all capture and handling events involving high risk species (critically endangered or narrowly endemic) or locations (e.g. isolated areas with endemic species, disjunct populations or high species richness). In situations where gloves are not available or suitable, hand washing with $70 \%$ ethanol (then allowing hands to air dry) between handling individual frogs is an alternative. If ethanol contact is maintained for $60 \mathrm{~s}$, most bacteria, fungi and viruses will be killed (see Table 1); however, repeated use on human skin is not recommended. If $70 \%$ ethanol is not available or suitable, the minimum recommended treatment is hand-washing in the water body to which the amphibian is naturally exposed. While rinsing in source water will not kill pathogens on hands, it may dislodge them and so exposure will not be increased greatly above background environmental levels. This treatment, however, needs to be tested further and should only be used for low risk species or locations.

When amphibians must be held temporarily, individuals should be housed in single-use containers (e.g. plastic bags) or in containers disinfected between each animal (Johnson et al. 2003, Webb et al. 2007, see Table 1). Adults should never be held in groups. Tadpoles from the same pond or stream section may be housed for short periods in a common container, though care must be taken to avoid overcrowding as this can increase transmission rates and cause physiological stress (Denver \& Crespi 2006). Longer holding times (>60 min) will require changes to water and the provision of appropriate food (when holding time is $>24 \mathrm{~h}$ ). Tadpoles of some species, particularly pondbreeding species with high fins, are easily damaged on capture and with movement of water within the holding container (E. Meyer pers. obs.). Rough handling of tadpoles of these species may, therefore, increase their susceptibility to trauma and infection. The requirements of tadpoles of each species should be considered when designing the capture and holding components of a field study. If animals are removed from the field and then returned, it should always be to the same site.

Dead amphibians or live animals showing clinical signs of disease must be regarded as having a high infection risk to healthy animals and rigorous hygiene measures are needed. No effective field treatment for chytridiomycosis has been demonstrated; however, infected frogs in captivity can be treated with elevated environmental temperatures (Woodhams et al. 2003, Retallick \& Miera 2007), itraconazole (Aguirre \& Lampo 2006, Pessier 2007) or chloramphenicol (Poulter et al. 2008) to clear Batrachochytrium dendrobatidis. These treatments require further validation in a range of species and some could be tested in the field in certain situations such as when recapture probabilities are high. No treatment regimes for ranaviral infection of frogs have been described; however, Johnson \& Wellehan (2005) suggest Zovirax ${ }^{\circledR}$ may be successful in controlling the disease. If successful these treatments could be used to lower the burden of disease in populations and reduce the risk of transmission and spread.

Sick and dead frogs should be collected for disease diagnosis. Disease surveillance may detect disease introduction and enable emergency responses. It is also useful to assess the risk of pathogen transmission to other individuals or spread to populations.

\section{Skin disinfection before and after invasive procedures}

Identifying individual amphibians during markrecapture studies is essential for determining survival, reproduction, home range, habitat preferences and incidence of infection. However, the method used for recognising animals must not significantly affect survival or behaviour. Therefore, strict hygiene standards must be maintained during amphibian marking procedures including implanting internal radio transmitters, passive integrated transponder (PIT) tags, visible implant alphanumeric (VIA) tags, visible implant elastomer (VIE) tags and toe tipping or clipping.

Amphibian skin is more permeable than skin of other vertebrates and requires special disinfectants. Alcohol, phenol and iodine based disinfectants will destroy mucus and wax that prevent dehydration and microbial infection of amphibian skin. These disinfectants are also potentially toxic and may be absorbed systemically (Wright 2001). The only suitable commercially available preparation for disinfecting wounds is Bactine ${ }^{\circledR}$ spray (active ingredient $0.14 \% \mathrm{w} / \mathrm{w}$ benzalkonium chloride and $2.6 \% \mathrm{w} / \mathrm{w}$ lidocaine hydrochloride in a non-alcohol base). Bactine ${ }^{\circledR}$ has been successfully used to treat amphibian wounds (Martin \& Hong 1991). Chlorhexidine $\left(0.75 \%\right.$ diluted from $2 \%$ Nolvasan $\left.{ }^{\circledR}\right)$ is also suitable for surgical disinfection (Wright 2001).

Betadine ${ }^{\circledR}$ disinfectant (active ingredient $1 \%$ povidone iodine) has been recommended for use on frogs before surgical procedures such as toe clipping (NSW NPWS 2001). However, iodine has caused toxic reac- 
tions in some amphibians (Wright 2001). Sensitivity, however, appears to be species-specific. Treatment with povidone iodine did not have adverse affects on the green tree frog Hyla cinerea (Brown 1995), but was implicated in rapid mortality of the harlequin poison frog Dendrobates histrionicus (Stoskopf et al. 1985). Therefore, we do not recommend Betadine ${ }^{\circledR}$ or other povidone-iodine products be used as disinfectants for an amphibian species until toxicity has been determined.

Application of a disinfectant before and after invasive procedures helps minimise pathogen entry from the skin to the wound. However, the protection provided is probably lost when the treated animal is released at the site of capture into a water body. The water-soluble antiseptics suitable for amphibians will dissolve upon contact with water. Therefore, for these treatments to be effective an extended holding time (e.g. $1 \mathrm{~h}$ ) is necessary before animals are released into or near water.

\section{Marking frogs}

Toe tipping (removal of most distal phalange) or toe clipping (amputation of a greater proportion of the digit) should occur through the interphalangeal joint. Johnson et al. (2003) recommend $70 \%$ ethanol as the most suitable disinfectant for use in field sterilisation of scissors to minimise the risk of transmitting Batrachochytrium dendrobatidis or ranaviruses. This treatment should be effective against most bacterial, viral and fungal pathogens.

PIT, VIE and VIA tags should be inserted with a sterile, single-use applicator. There is no clinical documentation of infection from any marking or tagging method; however, further controlled studies are required to conclusively demonstrate a limited effect on animal health and mobility (Phillott et al. 2007).

\section{Sealing open wounds}

The use of a cryanoacrylate compound such as Vetbond ${ }^{\circledR}$ (active ingredient n-butyl cryanoacrylate) as a tissue adhesive after toe tipping or clipping is possible in larger amphibians, but becomes increasingly difficult in smaller animals because it is difficult to isolate toes for application. Vetbond ${ }^{\circledR}$ can also be used to seal incisions made during subdermal injection of VIA, VIE and PIT tags. Moisture can interfere with setting times and adhesion (see Boothe 2003) so care must be taken to ensure setting has occurred before release. Problems may be experienced in their application to stream- or pond-dwelling amphibians, but can be avoided by using a small piece of sterile absorbent dressing to draw surplus water from the wound before application of the adhesive ( $\mathrm{H}$. B. Hines pers. obs.). Less expensive industrial adhesives ('superglues') should not be used as a replacement for surgical tissue glues as they have resulted in tissue death in other animals (see Wright 2001). Adhesives, such as Vetbond ${ }^{\circledR}$, may also trap microbes in the wound and promote infection (see Boothe 2003). To alleviate this problem a disinfectant such as Bactine ${ }^{\circledR}$ should be applied before the adhesive.

\section{Treatment of accessory equipment}

Appropriate disinfection strategies for accessory equipment such as nets, carry bags, clothing and footwear are listed in Table 1, which describes the minimum exposure time and disinfectant concentration shown to be effective on clean surfaces. No disinfectants should be applied where runoff could wash these into nearby water bodies. All equipment should be dry and cleaned of mud and organic debris before use, as this may reduce disinfection efficacy, then treated before use between sites (see next section).

\section{ENTRY, EXIT AND BETWEEN-SITE HYGIENE MEASURES}

Field biologists exposed to ill animals or their pathogens may pose an increased risk (above background levels) of spreading wildlife diseases. This risk is exacerbated by the ease and speed with which biologists can now move between sites and, more importantly, across natural barriers to disease spread (e.g. expanses of habitat unsuitable to amphibians or their pathogens such as deserts, mountain ranges and seas). It is therefore important that field biologists take steps to avoid increased risk of transmission of wildlife diseases between sites and populations.

Potential measures for reducing the likelihood of disease spread between sites are listed in Table 2 . These measures range in rigour from simple rinsing and drying of equipment through to the use of site-dedicated equipment and disinfection of vehicles. The purpose of these measures is not to eliminate pathogen spread entirely (as this may not be possible), but rather to avoid increased risk of spread above background levels. The stringency of hygiene measures to be implemented should, therefore, reflect the risk of field biologists spreading disease relative to background risk levels. This will depend on a range of factors including (1) activities undertaken before field work, (2) the nature of the proposed field work, (3) the remoteness 
Table 1. Disinfection strategies suitable for killing Batrachochytrium dendrobatidis and ranaviruses in field studies. Information for Batrachochytrium dendrobatidis is adapted from Berger (2001), Johnson et al. (2003) and Webb et al. (2007), and for ranaviruses from Langdon (1989), Miocevic et al. (1993) and Bryan et al. (2009)

\begin{tabular}{|c|c|c|c|c|}
\hline Application & Disinfectant & Strength & Time & Target pathogen \\
\hline \multirow{2}{*}{$\begin{array}{l}\text { Disinfecting surgical equip- } \\
\text { ment and other instruments } \\
\text { (e.g. scales, callipers) }\end{array}$} & Benzalkonium chloride & $2 \mathrm{mg} \mathrm{ml}^{-1}$ & $1 \mathrm{~min}$ & B. dendrobatidis \\
\hline & Ethanol & $70 \%$ & $1 \mathrm{~min}$ & $\begin{array}{l}\text { B. dendrobatidis, } \\
\text { Ranaviruses }\end{array}$ \\
\hline \multirow{3}{*}{$\begin{array}{l}\text { Disinfecting collection equip- } \\
\text { ment and containers }\end{array}$} & Sodium hypochlorite & $1 \%$ & $1 \mathrm{~min}$ & B. dendrobatidis \\
\hline & $\begin{array}{l}\text { (bleach contains } 4 \% \\
\text { sodium hypochlorite) }\end{array}$ & $3 \%$ & $1 \mathrm{~min}$ & Ranaviruses \\
\hline & $\begin{array}{l}\text { Path X or quaternary } \\
\text { ammonium compound } 128\end{array}$ & 1 in 500 dilution & $0.5 \min$ & B. dendrobatidis \\
\hline \multirow[t]{10}{*}{ Trigene } & 1 in 5000 dilution & $1 \mathrm{~min}$ & B. dendrobatidis & \\
\hline & F10 & 1 in 1500 dilution & $1 \mathrm{~min}$ & B. dendrobatidis \\
\hline & Virkon & $2 \mathrm{mg} \mathrm{ml}^{-1}$ & $1 \mathrm{~min}$ & B. dendrobatidis \\
\hline & & $1 \%$ & $1 \mathrm{~min}$ & Ranaviruses \\
\hline & Nolvasan & $0.75 \%$ & $1 \mathrm{~min}$ & Ranaviruses \\
\hline & Potassium permanganate & $1 \%$ & $10 \min$ & B. dendrobatidis \\
\hline & Complete drying & & $>3 \mathrm{~h}$ & B. dendrobatidis \\
\hline & Heat & $60^{\circ} \mathrm{C}$ & $30 \mathrm{~min}$ & $\begin{array}{l}\text { B. dendrobatidis, } \\
\text { Ranaviruses }\end{array}$ \\
\hline & Heat & $37^{\circ} \mathrm{C}$ & $8 \mathrm{~h}$ & B. dendrobatidis \\
\hline & Sterilising UV light & & $1 \mathrm{~min}$ & Ranaviruses only \\
\hline \multirow[t]{6}{*}{ Disinfecting footwear } & Sodium hypochlorite & $1 \%$ & $1 \mathrm{~min}$ & B. dendrobatidis \\
\hline & $\begin{array}{l}\text { (bleach contains } 4 \% \\
\text { sodium hypochlorite) }\end{array}$ & $3 \%$ & $1 \mathrm{~min}$ & Ranaviruses \\
\hline & $\begin{array}{l}\text { Path X or quaternary } \\
\text { ammonium compound } 128\end{array}$ & 1 in 500 dilution & $0.5 \min$ & B. dendrobatidis \\
\hline & Trigene & 1 in 5000 dilution & $1 \mathrm{~min}$ & B. dendrobatidis \\
\hline & F10 & 1 in 1500 dilution & $1 \mathrm{~min}$ & B. dendrobatidis \\
\hline & Complete drying & & $>3 \mathrm{~h}$ & B. dendrobatidis \\
\hline $\begin{array}{l}\text { Disinfecting cloth } \\
\text { (e.g. carry bags, clothes) }\end{array}$ & Hot wash & $60^{\circ} \mathrm{C}$ or greater & $30 \min$ & $\begin{array}{l}\text { B. dendrobatidis, } \\
\text { Ranaviruses }\end{array}$ \\
\hline
\end{tabular}

and frequency of human visitation of sites where work is being undertaken and (4) the presence or absence of known pathogens at a site.

In deciding on the rigour of between-site hygiene measures, consideration must be given not only to the aforementioned risk factors, but also the severity of the consequences of disease introduction for rare (geographically restricted) and threatened amphibian species. Since the implications of pathogen spread between sites for these species is probably more serious (potentially resulting in extinction of species or populations), more rigorous hygiene protocols may be appropriate, even where the risk posed by biologists is only slightly above background levels.

Given the above, deciding which measures are necessary and appropriate can be difficult, as can deciding on the geographical scale at which to apply be-
Table 2. Hygiene measures to be employed before visiting a study site grouped according to stringency

\begin{tabular}{|c|c|}
\hline Stringency & Hygiene measures \\
\hline Low & Clean and dry equipment and clothing \\
\hline Moderate & $\begin{array}{l}\text { Equipment that has been in contact with } \\
\text { amphibians or their habitat cleaned and } \\
\text { disinfected } \\
\text { Vehicle that has been at a site with } \\
\text { amphibians is cleaned }\end{array}$ \\
\hline High & $\begin{array}{l}\text { Site- or area-dedicated or disposable } \\
\text { field equipment or thorough cleaning } \\
\text { and disinfection of all clothing and } \\
\text { field equipment that has been in } \\
\text { contact with amphibians or their habitat } \\
\text { Vehicle that has been at a site with } \\
\text { amphibians is washed and disinfected }\end{array}$ \\
\hline
\end{tabular}


tween-site hygiene measures. Current hygiene guidelines provide limited assistance in defining the scale at which between-site hygiene protocols are applied. For example, NSW NPWS (2001) state that defining the boundary of a site may be problematic, but provide no criteria for making such assessments. We suggest that different levels of hygiene measures are appropriate between catchments of various sizes depending on the level of risk. For example highly stringent hygiene protocols are applied at the scale of small subcatchments when risk is high; less stringent protocols are required for larger catchments when relative risk is low.

To help simplify and standardise this decisionmaking process, we have developed a risk calculator, incorporating the risk factors and consequences identified above. Using this approach, field biologists can assess their risk of increased pathogen spread above background levels. An overall risk estimate is calculated that provides a quantitative measure that can assist field workers in determining the scale at which to apply between-site hygiene measures and the level of stringency required to reduce their risk (see Table 5). Given the diversity of environments encountered or activities undertaken during field studies, this risk calculator is best viewed as a framework that can be modified to suit particular circumstances. Its use, however, will ensure that there is greater consistency among field biologists in their application of hygiene protocols.
To assess the risk of increased pathogen spread, each of the 4 risk factors identified previously is scored against criteria described below and listed in Table 3.

\section{Risk 1: prior activity}

Activities in the days ( 2 to 3 d) before field work begins can greatly increase risk of pathogen spread particularly where these involve work with exotic (nonlocal) captive amphibians, pathogen cultures or infected amphibians. This is because pathogen survival on fomites or mechanical vectors generally decreases exponentially with time. Involvement in such activities necessitates the implementation of more stringent hygiene measures, particularly entry protocols. For this reason we have given activities associated with working with pathogens or known infected or captive amphibians an order of magnitude greater score (100 points) versus the maximum of 10 points for other risk factors. This high score can be reduced to 10 if working under biosecure conditions such as in a level 2 biosecurity (PC2) facility. Working on apparently healthy amphibians and aquatic environments in areas harbouring known pathogens or diseases receives a score of 10 unless those amphibians have disease, in which case the score is 100. Working on amphibians and aquatic environments in uninfected areas receives a score of 7 because pathogens of amphibians are poorly known and it is

Table 3. Risk factors, criteria and scores used to determine the total risk score for pathogen spread to a study site. The overall risk score is obtained by summing the scores for each of the 4 risk factors

\begin{tabular}{|c|c|c|}
\hline Risk factor & Criteria & Score \\
\hline \multirow[t]{4}{*}{ 1. Prior activity $(\sim 2-3 \mathrm{~d})$} & $\begin{array}{l}\text { (a) Worked with exotic (nonlocal) captive amphibians or amphibians with } \\
\text { significant infectious or potentially significant infectious diseases or in } \\
\text { a laboratory with significant amphibian pathogen cultures }\end{array}$ & 100 \\
\hline & $\begin{array}{l}\text { (b) Targeted apparently healthy amphibians or aquatic environments in } \\
\text { areas where significant amphibian pathogens are known to be present } \\
\text { or status is unknown }\end{array}$ & 10 \\
\hline & $\begin{array}{l}\text { (c) Targeted apparently healthy amphibians or aquatic environments in } \\
\text { areas where significant amphibian pathogens are known to be absent }\end{array}$ & 7 \\
\hline & (d) Did not target amphibians or aquatic environments & 1 \\
\hline \multirow[t]{2}{*}{ 2. Proposed activity at the study site } & (a) Directed towards amphibians or aquatic environments & 10 \\
\hline & (b) Not directed towards amphibians or aquatic environments & 1 \\
\hline \multirow[t]{4}{*}{ 3. Remoteness of the study site } & $\begin{array}{l}\text { (a) Isolated or difficult to access area; human visitation rare } \\
\left(\text { e.g. }<100 \text { visitors } \mathrm{yr}^{-1}\right)\end{array}$ & 10 \\
\hline & (b) Visitation low (e.g. 100-999 visitors $\mathrm{yr}^{-1}$ ) & 7 \\
\hline & (c) Visitation moderate (e.g. 1000-9999 visitors $\mathrm{yr}^{-1}$ ) & 3 \\
\hline & (d) Visitation high; area highly disturbed and/or populated & 1 \\
\hline \multirow[t]{2}{*}{ 4. Presence of pathogen at the study site } & $\begin{array}{l}\text { (a) Significant amphibian pathogens are known to be absent or } \\
\text { status is unknown }\end{array}$ & 10 \\
\hline & (b) Significant amphibian pathogens are known to be present & 5 \\
\hline
\end{tabular}


possible that an undiscovered pathogen occurs there. When field workers did not target amphibians or aquatic environments this receives a score of 1 , as encountering amphibian pathogens is much less likely to occur (Table 3).

\section{Risk 2: proposed activity}

The nature of the proposed field work influences the risk of spread. Activities directly targeting amphibians or aquatic environments, such as mark-recapture studies, are likely to increase the risk of pathogen spread between sites and are given a score of 10. Other field activities not directly targeting amphibians but which take place within known amphibian habitat, such as a mammal survey, may also increase the risk of pathogen spread, although at a much lower likelihood, and are given a score of 1 (Table 3).

\section{Risk 3: remoteness of site}

For accessible areas subject to high levels of human visitation, the value in field workers applying rigorous between-site hygiene measures may be reduced, as the background risk of pathogen spread by human activities is high. Where field biologists are accessing remote rarely visited areas, however, the potential for introducing new pathogens is relatively much higher compared with background levels, necessitating the adoption of more stringent hygiene measures. Consequently, we have scaled the relative risk by setting the criterion scores based on the level of total human visitation to the area (Table 3 ).

\section{Risk 4: presence of known pathogens}

If the area to be visited is known to be free of significant amphibian pathogens, then the risk posed by disease spread is likely to be higher, necessitating more stringent hygiene measures. Where the disease status of sites is unknown or poorly known, we recommend a precautionary approach whereby a site is assumed to be pathogen-free and is also given a score of 10. Sites with known pathogens are given a score of 5 as pathogens of amphibians are poorly known and it is possible that an undiscovered significant pathogen could be introduced (Table 3). The status of amphibian disease at a site is particularly important for exit protocols, i.e. if a disease capable of causing mass mortality (e.g. chytridiomycosis, ranaviral disease) is known from an area then it is important to thoroughly disinfect everything before leaving that area. Transferring water, substrates, plant material or animals between sites can spread pathogens and should be strictly avoided unless they can be guaranteed to be pathogen-free.

\section{Calculating and applying the overall risk estimate}

The scores for each of the above factors are summed to produce a total risk score. This total risk score is multiplied by the consequence score, a value reflecting the International Union for Conservation of Nature (IUCN) conservation status (IUCN 2001) of amphibian species known or likely to occur within the area of the proposed activity (Table 4 ). The resulting overall risk score is then used to decide what hygiene measures are required to ensure pathogen transmission is not increased above background levels, as well as the scale at which these measures should be applied between sites (i.e. between major or minor subcatchments) (see Table 5).

An overall risk score of less than 150 indicates that the relative risk of a field biologist spreading pathogens is low and that between-site hygiene measures required are simple and applied at the broad scale of major catchments. An overall risk score in excess of 300 indicates that the relative risk posed by the field biologist is high and that between-site hygiene measures required to reduce this risk are stringent and applied at the fine scale of minor subcatchments (i.e. stream orders 1 and 2; Strahler 1952) within the area to be visited (Table 5). While the scores calculated by our system are relative and not absolute, they are useful in ensuring that key aspects of the risk of pathogen spread are considered when deciding which between-site hygiene measures to use.

Five examples of the application of the risk calculator are provided in Table 6. The highest overall risk score is for a graduate student conducting research on endemic frog species in remote areas where the status

Table 4. Criteria and consequence score for pathogen spread to the major catchment around the study site

\begin{tabular}{|lc|}
\hline Criteria & Score \\
\hline $\begin{array}{l}\text { The major catchment where the proposed activity } \\
\text { is to be undertaken supports: }\end{array}$ & \\
$\begin{array}{l}\text { (a) at least 1 critically endangered species or has } \\
\quad \text { endemic species }\end{array}$ & 10 \\
(b) at least 1 endangered species & 8 \\
(c) at least 1 vulnerable species & 6 \\
(d) at least 1 near-threatened species & 4 \\
(e) at least 1 amphibian (native or exotic) species & 3 \\
(f) no amphibians (known or likely) & 1 \\
\hline
\end{tabular}


Table 5. Overall relative risk score for pathogen transmission between sites by summing the scores for risk factors in Table 3 (the total risk score) as defined by Strahler (1952)

\begin{tabular}{|c|c|c|c|}
\hline & High & Medium & Low \\
\hline Overall risk score & $>300$ & $150-300$ & $<150$ \\
\hline $\begin{array}{l}\text { Entry and exit } \\
\text { protocols }\end{array}$ & Stringent & Moderate & Low \\
\hline $\begin{array}{l}\text { Scale at which } \\
\text { hygiene is } \\
\text { required }\end{array}$ & $\begin{array}{l}\text { Between minor } \\
\text { subcatchments } \\
\text { (e.g. stream } \\
\text { order 1-2) }\end{array}$ & $\begin{array}{l}\text { Between major } \\
\text { subcatchments } \\
\text { (e.g. stream } \\
\text { order } 3-4)\end{array}$ & $\begin{array}{l}\text { Between major } \\
\text { catchments } \\
\text { (e.g. stream } \\
\text { order } \geq 5 \text { ) }\end{array}$ \\
\hline
\end{tabular}
and subsequent hygiene requirements. The overall risk score is obtained and multiplying by the consequence score from Table 4 . Stream order is

tial to carry subclinical diseases and parasites not native to the local area. The zookeeper, therefore, must apply stringent hygiene measures before commencing monitoring. In contrast a volunteer from the local community helping the zookeeper with monitoring poses a much smaller relative risk as they have not been in contact with exotic captive amphibians and the area targeted for monitoring is highly disturbed. We recommend the use of low stringency hygiene measures by this volunteer (i.e. use of clean and dry personal equipment and clothing) due to this low relative risk.

The remaining 2 examples of the risk of amphibian diseases is not known. As this student is targeting frogs, their probability of spreading a new disease is relatively high and the consequence of this is also high due to the presence of locally endemic species. Therefore, highly stringent hygiene protocols applied at a small scale are recommended.

An amphibian keeper from a zoo that holds exotic frogs and who wishes to undertake monitoring of frogs in a local urban area, also has a relatively high risk of spreading a new disease, due to the keeper's potential exposure to exotic pathogens. These captive frogs have been sourced from a number of localities, including international ones, so they have the poten- calculator in Table 6 compare 2 cases where a government officer is undertaking amphibian survey and monitoring activities. If human visitation is high and the targeted area is only likely to support frogs with a relatively low risk of extinction, then the relative risk is low and only a low stringency of hygiene measures is required. However, where the officer is moving from site to site, including areas with chytridiomycosis present, and targeting endangered frogs, the relative risk is higher and so the hygiene measures need to be more stringent. The measures will become even more stringent if any of the monitored frogs have chytridiomycosis.

Table 6. Examples of the application of the risk calculator using 5 scenarios. RF1-4 refers to risk factors 1 to 4 and their criteria scores as shown in Table 3. The total risk score is the sum of the scores for risk factors 1 to 4 . The overall risk score is calculated by multiplying the total risk score by the consequence score (Table 4 )

\begin{tabular}{|c|c|c|c|c|c|c|c|}
\hline Scenario & RF1 & RF2 & RF3 & RF4 & $\begin{array}{c}\text { Total } \\
\text { risk score }\end{array}$ & $\begin{array}{c}\text { Consequence } \\
\text { score }\end{array}$ & $\begin{array}{c}\text { Overall } \\
\text { risk score }\end{array}$ \\
\hline $\begin{array}{l}\text { 1. A graduate student is studying frog speciation } \\
\text { and endemism on remote mountain tops in Bor- } \\
\text { neo where disease status is unknown }\end{array}$ & 10 & 10 & 10 & 10 & 40 & 10 & 400 \\
\hline $\begin{array}{l}\text { 2. An amphibian keeper from a zoo that holds } \\
\text { exotic frogs is planning to undertake monitoring } \\
\text { of nonthreatened frogs in an urban area where } \\
\text { disease outbreaks have not been observed }\end{array}$ & 100 & 10 & 1 & 10 & 121 & 3 & 363 \\
\hline $\begin{array}{l}\text { 3. A community volunteer who does not hold } \\
\text { a collection of exotic amphibians is assisting in } \\
\text { the above survey of urban frogs }\end{array}$ & 1 & 10 & 1 & 10 & 22 & 3 & 66 \\
\hline $\begin{array}{l}\text { 4. A government officer is undertaking a one-time } \\
\text { survey of amphibian species at a popular swim- } \\
\text { ming spot in a national park where a species } \\
\text { considered vulnerable is likely to occur }\end{array}$ & 1 & 10 & 3 & 10 & 24 & 6 & 144 \\
\hline $\begin{array}{l}\text { 5. A government officer is regularly monitoring } \\
\text { populations of apparently healthy endangered } \\
\text { frogs in national parks with moderate levels of visita- } \\
\text { tion and where chytridiomycosis is known to occur }\end{array}$ & $10^{\mathrm{a}}$ & 10 & 3 & 5 & 28 & 8 & 224 \\
\hline
\end{tabular}




\section{Determining the order of visitation of multiple field sites}

When a field trip encompasses several field sites, or a number of locations are being visited in succession within 2 to $3 \mathrm{~d}$ of each other, the order of visitation should be determined according to the presence of known pathogens and diseases. While unknown pathogens obviously cannot be accounted for, areas known to be absent of disease should be visited first, followed by areas of unknown status and then known infected areas.

\section{Return of captive animals to the wild}

If wild amphibians are housed for any period of time in a captive situation (e.g. laboratory, zoo or captive breeding facility), we do not recommend that they be returned to their natural population unless they have been kept in isolation, their captive history is free of undiagnosed morbidity or mortality and they have had rigorous pathogen screening before release. This is usually beyond the means of most studies. Thus, when assessing permits for such an activity, wildlife conservation agencies and ethics committees should view animals taken from the wild as a permanent take.

\section{CONCLUSIONS}

In the absence of detailed studies quantifying the effect of research and monitoring procedures on transmission and spread of pathogens, these guidelines provide researchers with the most appropriate and effective methods for minimising exposure of amphibians to pathogens within and among field sites. Prevention or failure to prevent transmission and spread of infection despite best hygiene practice should be documented to improve guidelines.

In addition to minimising exposure of amphibians to pathogens during field studies, our between-site hygiene recommendations may also be useful in preventing the spread of nonamphibian pathogens, such as the plant fungal pathogen Phytophthora cinnamomi, and weeds. Our hygiene principles may be used as a basis when developing pathogen transmission and spreadrisk minimisation guidelines for other people such as recreational fishers or for pathogens of other taxa.

\section{LITERATURE CITED}

AGDAFF (Australian Government Department of Agriculture, Fisheries and Forestry) (2009) Import risk analysis handbook 2007 (update 2009). AGDAFF, Canberra. www.daff.gov. au/_data/assets/pdf_file/0003/1177833/IRA_handbook_ 2009_FINAL_FOR_WEB.pdf. Accessed 3 Aug 2009
Aguirre AA, Lampo M (2006) Protocolo de bioseguridad y cuarentena para prevenir la transmisión de enfermedades en anfibios. In: Angulo A, Rueda-Almonacid JV, Rodríguez-Mahecha JV, La Marca E (eds) Técnicas de inventario y monitorei para los anfibios de la región tropical Andina. Conservación Internacional Serie Manuales de Campo No. 2. Panamericana Formas e Inpresos, Bogotá, p 73-92

Berger L (2001) Diseases in Australian frogs. PhD thesis, James Cook University, Townsville

> Berger L, Speare R, Daszak P, Green DE and others (1998) Chytridiomycosis causes amphibian mortality associated with population declines in the rainforests of Australia and Central America. Proc Natl Acad Sci USA 95:9031-9036

Berger L, Speare R, Hyatt A (1999) Chytrid fungi and amphibian declines: overviews, implications and future directions. In: Campbell A (ed) Declines and disappearances of Australian frogs. Environment Australia, Canberra, p 23-33

Boothe HW (2003) Suture materials, tissue adhesives, staplers, and ligating clips. In: Slatter D (ed) Textbook of small animal surgery. Saunders, Philadelphia, PA, p 235-244

Brown CS (1995) Rear leg amputation and subsequent adaptive behavior during introduction of a green treefrog, Hyla cinerea. Bull Assoc Reptilian Amphibian Vet 5:6-7

Bryan LK, Baldwin CA, Gray MJ, Miller DL (2009) Efficacy of select disinfectants at inactivating Ranavirus. Dis Aquat Org 84:89-94

> Carey C, Cohen N, Rollins-Smith L (1999) Amphibian declines: an immunological perspective. Dev Comp Immunol 23:459-472

Cashins SD, Alford RA, Skerratt LF (2008) Lethal effect of latex, nitrile, and vinyl gloves on tadpoles. Herpetol Rev 39:298-301

CCADC (California Centre for Amphibian Disease Control) (2008) Decontamination protocol to reduce the risk of spreading infectious amphibian diseases in freshwater systems. www.ccadc.us/docs/DeconForProfessionals.pdf. Accessed 27 Oct 2008

Cunningham AA, Langton TES, Bennett PM, Lewin JF, Drury SEN, Gough RE, Macgregor SK (1996) Pathological and microbiological findings from incidents of unusual mortality of the common frog (Rana temporaria). Philos Trans R Soc Lond B Biol Sci 351:1539-1557

- Cunningham AA, Garner TWJ, Aguilar-Sanchez V, Banks B and others (2005) Emergence of amphibian chytridiomycosis in Britain. Vet Rec 157:386-387

$>$ Daszak P, Berger L, Cunningham AA, Hyatt AD, Green DE, Speare R (1999) Emerging infectious diseases and amphibian population declines. Emerg Infect Dis 5:735-748

Daszak P, Cunningham AA, Hyatt AD (2001) Draft guidelines for international translocation of amphibians with respect to infectious diseases. In: Speare R (ed) Developing management strategies to control amphibian diseases: decreasing the risks due to communicable diseases. School of Public Health and Tropical Medicine, James Cook University, Townsville. www.jcu.edu.au/school/ phtm/PHTM/frogs/ampdis.htm. Accessed 27 Oct2008

$>$ Daszak P, Cunningham AA, Hyatt AD (2003) Infectious disease and amphibian population declines. Divers Distrib 9:141-150

Daszak P, Schloegel LM, Maranda L, Cronin L, Pokras M, Smith K, Picco A (2006) The global trade in amphibians: summary interim report of a CCM study. Consortium for Conservation Medicine, New York. www.conservationmedicine.org/factsheets/Amphib_trade_ interim_report_06.pdf. Accessed 27 Oct 2008 
Denver RJ, Crespi EJ (2006) Stress hormones and human developmental plasticity: lessons from tadpoles. NeoReviews 7:183-188

Fisher MC, Garner TWJ (2007) The relationship between the emergence of Batrachochytrium dendrobatidis, the international trade in amphibians and introduced amphibian species. Fung Biol Rev 21:2-9

Green DE, Converse KA, Schrader AK (2002) Epizootiology of sixty-four amphibian morbidity and mortality events in the USA, 1996-2001. Ann NY Acad Sci 969:323-339

Gutleb AC, Bronkhorst M, van den Berg JHJ, Murk AJ (2001) Latex-laboratory-gloves: an unexpected pitfall in amphibian toxicity assays with tadpoles. Environ Toxicol Pharmacol 10:119-121

HACC (Herpetological Animal Care and Use Committee) (2004) Guidelines for use of live amphibians and reptiles in field and laboratory research, 2nd edn. Am Soc Ichthyol Herpetol, Lawrence, KS. www.asih. org/files/hacc-final. pdf. Accessed 27 Oct 2008

- Hanselmann R, Rodriguez A, Lampo M, Fajardo-Ramos L and others (2004) Presence of an emerging pathogen of amphibians in introduced bullfrogs Rana catesbeiana in Venezuela. Biol Conserv 120:115-119

IUCN (International Union for Conservation of Nature) (2001) IUCN red list categories and criteria: version 3.1. IUCN Species Survival Commission, IUCN, Gland, Switzerland, and Cambridge, UK

Jancovich JK, Davidson EW, Parameswaran N, Mao J and others (2005) Evidence for emergence of an amphibian iridoviral disease because of human-enhanced spread. Mol Ecol 14:213-224

> Johnson AJ, Wellehan JFX (2005) Amphibian virology. Vet Clin N Am Exotic Anim Pract 8:53-65

Johnson ML, Berger L, Philips L, Speare R (2003) Fungicidal effects of chemical disinfectants, UV light, desiccation and heat on the amphibian chytrid Batrachochytrium dendrobatidis. Dis Aquat Org 57:255-260

Langdon JS (1989) Experimental transmission and pathogenicity of epizootic haematopoietic necrosis virus (EHNV) in red fin perch, Perca fluviatilis L., and 11 other teleosts. J Fish Dis 12:295-310

Lips KR, Brem F, Brenes R, Reeve JD and others (2006) Emerging infectious disease and the loss of biodiversity in a Neotropical amphibian community. Proc Natl Acad Sci USA 103:3165-3170

Lips KR, Diffendorfer J, Mendelson JR III, Sears MW (2008) Riding the wave: reconciling the roles of disease and climate change in amphibian declines. PLoS Biol 6:e72 doi:10.1371/journal.pbio.0060072

Longcore JE, Pessier AP, Nichols DK (1999) Batrachochytrium dendrobatidis gen. et sp. nov., a chytrid pathogenic to amphibians. Mycologia 91:219-227

Martin D, Hong H (1991) The use of Bactine ${ }^{\circledR}$ in the treatment of open wounds and other lesions in captive anurans. Herpetol Rev 22:21

Mazzoni R, Cunningham AC, Daszak P, Apolo A, Perdomo E, Speranza G (2003) Emerging pathogen of wild amphibians in frogs (Rana catesbeiana) farmed for international trade. Emerg Infect Dis 9:995-998

Mendez D, Webb R, Berger L, Speare R (2008) Survival of the amphibian chytrid fungus Batrachochytrium dendrobatidis on bare hands and gloves: hygiene implications for amphibian handling. Dis Aquat Org 82:97-104

> Miocevic I, Smith J, Owens L, Speare R (1993) Ultraviolet sterilisation of model viruses important to finfish aquaculture in Australia. Aust Vet J 70:25-27

Muths E, Corn PS, Pessier AP, Green DE (2003) Evidence for disease-related amphibian decline in Colorado. Biol Conserv 110:357-365

Mutschmann F, Berger L, Zwart P, Gaedicke C (2000) Chytridiomycosis on amphibians-first report from Europe. Berl Munch Tierarztl Wochenschr 113:380-383

NSW NPWS (New South Wales National Parks and Wildlife Service) (2001) Hygiene protocol for the control of disease in frogs. Threatened Species Management Information Circular No. 6. www.environment.nsw.gov.au/resources/nature/ hyprfrog. pdf. Accessed 23 Jan 2008

NWHC (National Wildlife Health Center) (2001) Toe-clipping of frogs and toads standard operating procedure no. 110. NWHC, Madison, WI www.nwhc.usgs.gov/publications/ amphibian_research_procedures/toe_clipping.jsp. Accessed 27 Oct 2008

Oevermann A, Schildger B, Feldman S, Robert N (205) Chytridiomykosis in amphibians (Dyscophus antongilii) in Switzerland. Tierarztl Umschau 60:211

OIE (World Organisation of Animal Health) (2008) Infection with Batrachochytrium dendrobatidis. OIE, Paris. www.oie.int/eng/normes/fcode/fcode2008/. Accessed 27 Oct 2008

> Parker JM, Mikaelian I, Hahn N, Diggs HE (2002) Clinical diagnosis and treatment of epidermal chytridiomycosis in African clawed frogs (Xenopus tropicalis). Comp Med 52:265-268

> Pearman PB, Garner TWJ, Straub M, Greber UF (2004) Response of the Italian frog (Rana latastei) to a Ranavirus, frog virus 3: a model for viral emergence in naive populations. J Wildl Dis 40:660-669

Pessier AP (2007) Approaches to the control and treatment of Batrachochytrium infection in captive amphibian collections. In: Amphibian declines and chytridiomycosis: translating science into urgent action. Tempe, AZ, 5-7 November 2007, p 21-22, www.parcplace.org/documents/Bd_ Program_post-FINAL.pdf

Phillott AD, Skerratt LF, McDonald KR, Lemckert FL and others (2007) Toe-clipping as an acceptable method of identifying individual anurans in mark recapture studies. Herpetol Rev 38:305-308

> Picco AM, Collins JP (2009) Amphibian commerce as a likely source of pathogen pollution. Conserv Biol 22:1582-1589

Picco AM, Brunner JL, Collins JP (2007) Susceptibility of the endangered California tiger salamander, Ambystoma californiense, to ranavirus infection. J Wildl Dis 43:286-290

Poulter R, Bishop P, Speare R (2008) A protocol for treating chytrid (Batrachochytrium dendrobatidis)-infected frogs. University of Otago, Dunedin. www.nzfrogs.org/site/ nzfrog/files/Treatment\%20Protocol.pdf. Accessed 27 Oct 2008

Raverty S, Reynolds T (2001) Cutaneous chytridiomycosis in dwarf aquatic frogs (Hymenochirus boettgeri) originating from southeast Asia and in a western toad (Bufo boreas) from northeastern British Columbia. Can Vet J 42: 385-386

Retallick RWR, Miera V (2007) Strain differences in the amphibian chytrid Batrachochytrium dendrobatidis and non-permanent, sub-lethal effects of infection. Dis Aquat Org 75:201-207

Schloegel LM, Hero JM, Berger L, Speare R, McDonald K, Daszak P (2006) The decline of the sharp-snouted day frog (Taudactylus acutirostris): the first documented case of extinction by infection in a free-ranging wildlife species? EcoHealth 3:35-40

Skerratt LF, Berger L, Speare R, Cashins S and others (2007) Spread of chytridiomycosis has caused the rapid global decline and extinction of frogs. EcoHealth 4:125-134 
Speare R, Berger L, Skerratt LF, Alford R and others (2004) Hygiene protocol for handling amphibians in field studies. James Cook University, Townsville. www.jcu.edu.au/ school/phtm/PHTM/frogs/field-hygiene.pdf. Accessed 27 Oct 2008

Stoskopf MK, Wisnieski A, Pieper L (1985) Iodine toxicity in poison arrow frogs. Proc Am Assoc Zoo Vet 1985:86-88

Strahler AN (1952) Hypsometric (area-altitude) analysis of erosional topography. Geol Soc Am Bull 63:1117-1142

Webb R, Mendez D, Berger L, Speare R (2007) Additional disinfectants effective against the amphibian chytrid fun-

Editorial responsibility: Alex Hyatt,

Geelong, Victoria, Australia gus Batrachochytrium dendrobatidis. Dis Aquat Org 74: $13-16$

Weldon C, du Preez LH, Hyatt AD, Muller R, Speare R (2004) Origin of the amphibian chytrid fungus. Emerg Infect Dis 10:2100-2105

Woodhams DC, Alford RA, Marantelli G (2003) Emerging disease of amphibians cured by elevated body temperature. Dis Aquat Org 55:65-67

Wright KM (2001) Surgical techniques. In: Wright KM, Whitaker BR (eds) Amphibian medicine and husbandry. Krieger Publishing, Malabar, FL, p 273-283

Submitted: March 16, 2009; Accepted: October 4, 2009

Proofs received from author(s): January 19, 2010 